\author{
Michał PODNIESIŃSKI \\ Uniwersytet Jagielloński \\ E-mail: michal.podniesinski@uj.edu.pl
}

\title{
„CZŁOWIEK SZALONY POWIEDZIAŁ SOBIE, W SWYM SERCU, ŻE NIE MA TAKIEJ RZECZY, JAK SPRAWIEDLIWOŚĆ...”
}

\section{W STRONĘ PAŃSTWA TRANSCENDENTALNEGO. KILKA KOLEJNYCH UWAG W SPORZE Z HOBBESEM}

ABSTRACT “The fool hath said in his heart, there is no such thing as justice...” In Favor of Transcendental State. Several other Arguments in Dispute with Hobbes This paper is one of several articles focused on the theory of contract and the foundations of the modern liberal society. It is a continuation of the pervious paper: Why the Anglosaxon do not like Foucault? The text consists of two major parts. First is an analysis of a modern attempt to defend contractarianism by such authors as D. Gauthier, G. Kavka, J. Hampton, K. Hoekstra, M. Oakeschott, S.M. Brown and their argumentation, especially an attempt to interpret Hobbes in game theory categories. It is discredited as full of logical errors. In the second part, two new arguments against the theory of contract are introduced: (I) historical one - reality proved that human act rather conversely than Hobbes wanted them to, and (II) logical - based on the priority of mutuality rule as fundamental in human cognition.

KEY WORDS theory of contract, liberal State, rational choice theory, game theory, Hobbes, natural law, state of nature

W naszym poprzednim artykule Dlaczego Anglosasi nie lubia Foucaulta?" stwierdziliśmy, co następuje: nie ma możliwości przejścia pomiędzy stanem natury 
a porządkiem politycznym. Poucza nas o tym dogłębne zrozumienie myśli Michela Foucaulta, którego kilka zasadniczych dzieł winno być właśnie tak interpretowanych ${ }^{2}$. Za tym twierdzeniem przemawia przynajmniej kilka podstawowych argumentów.

Na najbardziej podstawowym poziomie pojawia się problem z agregacją władz ludzkich w stanie natury, rozumianych jako proste fizyczne dyspozycje do robienia czegośs. Uświadomiło to nam jednak znacznie ważniejszy problem, a mianowicie bardzo poważny błąd ekwiwokacji ${ }^{4}$ w użyciu terminu „uprawnienie”, który umożliwia domniemanie prawdziwości w stosunku do twierdzenia, że możliwe jest zrzeczenie się uprawnienia. Jest to jednak twierdzenie fałszywe, ponieważ gdy przeanalizujemy dokładnie Hobbesowską definicję uprawnienia, dostrzeżemy, że jest ono - zgodnie zresztą z podstawowymi założeniami mechanistycznej antropologii Hobbesa i logiką stanu natury jedynie prostą dyspozycją, której z istoty zrzec się nie można 5 .

Oba te problemy skutkują bardzo poważnymi komplikacjami na poziomie politycznym. Okazuje się bowiem, że Hobbes przez ostatnie kilkaset lat był zupełnie mylnie odczytywany jako teoretyk przejścia ze stanu przedpolitycznego do stanu politycznego, co jest oczywistą nieprawdą, jako że z jego dzieła wynika coś zupełnie innego. Cała argumentacja Hobbesa może być uznana co najwyżej za teorię przejścia ze stanu anarchii do stanu „niewolnictwa”. W tym miejscu wzmacniamy jeszcze nasze stanowisko względem wcześniejszych wniosków ${ }^{6}$, choć wydaje się, że i stan tyranii nie powinien być rozpatrywany jako stan polityczny ${ }^{7}$.

M. Foucault, Foucault Reader, ed. P. Rabinow, New York 1984, s. 63. A także: tenże, Power/Knowledge. Selected Interviews and Other Writings 1971-1977, ed. C. Gordon, New York 1980, s. 88-89, 188, 199.

3 B. Hindess, Filozofie wtadzy. Od Hobbesa do Foucaulta, przeł. D. Leszczyński, L. Rasiński, WarszawaWrocław 1999, s. 53.

4 Błąd ekwiwokacji jest permanentnie popełniany przez Hobbesa. Jean Hampton dowodzi np., że popełnia on ten błąd także w przypadku pojęcia suwerena, zgodnie z jego własną logiką argumentu z regresu rozumianego jako osoba, która ma wtadzę decydowania we wszystkich zagadnieniach we wspólnocie, dzierżąc wtadze nieprzerwanie tak dtugo jak dtugo ma możność o nich decydowania (J. Hampton, Hobbes and Social Contract Tradition, Cambridge 1986, s. 198). Pozostaje to bowiem w jaskrawej sprzeczności z prawem do samozachowania, którego nikt się nie może zrzec - podmioty dają rzekomo suwerenowi coś, czego mu dać nie mogą (tamże, s. 199-200), a więc i suweren nigdy nie posiądzie tego, co jest jego definicyjnym warunkiem. Stąd wniosek, iż Hobbes mówi o suwerenie w dwóch różnych znaczeniach. Jest to więc dokładnie ten sam problem, który spostrzegliśmy, lecz w związku z analizą innej kategorii; co bynajmniej nie redukuje samego błędu ekwiwokacji.

5 George Panichas, analizując już samo pojęcie prawa, wprowadza dwa warunki: 1) logicznej korelacji: musi być możliwość wskazania, po której stronie rodzą się obowiązki w stosunku do prawa, które komuś przyznajemy, oraz 2) moralnej korelacji: muszą rzeczywiście istnieć takie osoby. (G.E. Panichas, Hobbes, Prudence and Basic Rights, „Noûs” 1988, Vol. 22, nr 4, s. 558-559).

6 W znacznej mierze pod wpływem lektury klasycznego opracowania Jean Hampton: Relacja pomiędzy absolutnym suwerenem a jego poddanymi jest doktadnie taka sama jak pomiędzy panem i niewolnikiem. Dla Hobbesa wojna się kończy, gdy kazdy z nas zostanie uczyniony niewolnikiem i poddany rozkazom jednego: cena zatem pokoju jest zniszczenie wszystkich poza jedna wola (J. Hampton, Hobbes and Social Contract Tradition, s. 104).

Zob.: L. Strauss, O tyranii, red. V. Gourevitch, M.S. Roth, przeł. P. Armada, A. Górnisiewicz, Kraków 2009, Politika. 
Podobny argument stosuje się do przejścia od egoistycznego zwierzęcia, kierującego się ślepym samozachowaniem, do przyzwoitego gentlemana, który dotrzymuje umów i kłania się kobietom. Wydaje się ono możliwe, ponieważ w kluczowym momencie wywodu ucieka się do nieuprawnionego zapośredniczenia w „dziwnej” wszechwiedzącej świadomości, a ponadto argumentuje z konsekwencji, które w ogóle nie mogą być brane pod uwagę w stanie natury.

Artykuł nasz kończyliśmy wnioskami, że to właśnie Michelowi Foucaultowi zawdzięczamy dogłębne wykazanie niebezpieczeństw, jakie tkwią w fundowaniu społeczeństw na teoriach kontraktualnych, jako że wykazanie ich błędności wprost prowadzi do skrajnie naturalistycznych i darwinistycznych wniosków, które można zamknąć $\mathrm{w}$ prostym stwierdzeniu, że nasz obecny świat polityczny to permanentny stan natury. Bowiem po serii krwawych rewolucji, które jaskrawo sprzeniewierzyły się transcendentalnemu charakterowi państwa, nieustannie osuwa się ono w coraz głębszy i bardziej prymitywny utylitaryzm, coraz częściej i brutalniej ingerujący w sferę nagiego życia ${ }^{8}$.

Obecny artykuł jest więc próbą zarówno rozszerzenia, jak i pogłębienia tej refleksji. Mogą bowiem znaleźć się osoby, które nie będą usatysfakcjonowane naszą nadrzędną linią interpretacji, że Foucault w znacznym stopniu podważał cata tradycję angielskiego kontraktualizmu, jako że jest on po prostu znacznie bardziej złożony. Nawet jeśli zgodzić się na to - mógłby ktoś ripostować - jest to jeszcze za mało, by sam kontraktualizm utożsamiać z anglosaską refleksją polityczną, która jest znacznie bogatsza; dość wskazać Davida Hume’a i cały nurt utylitarystyczny ${ }^{9}$. Nawet jeśli i na to przystać - kontynuowałby ktoś - poważnym uchybieniem omawianego artykułu było powołanie się jedynie na krytyków kontraktualizmu, tak jakby nie był on w stanie bronić się sam.

Wszystkie powyższe wątpliwości postaramy się rozwiać w części pierwszej niniejszego artykułu, gdzie w miarę wiernie i zarazem twórczo zostanie naszkicowana debata wokół tak ważnej sytuacji przystąpienia do umowy społecznej, po raz pierwszy

Zob. szczególnie: M. Foucault, Rzadomyślność, [w:] L. Rasiński, D. Leszczyński, Historia, wtadza, polityka, Warszawa-Wrocław 2002, s. 163-185. Rozważania Foucualta zapoczątkowały dość bogaty nurt badań nad władzą jako zjawiskiem. Jednym z najważniejszych badaczy podążaących tą drogą stał się ostatnimi czasy Giorgio Agamben (zob.: G. Agamben, Stan wyjątkowy, przeł. M. Surma-Gawłowska, posł. G. Jankowicz, P. Mościcki, Kraków 2008, Linia Krytyczna, 2; tenże, Homo sacer. Suwerenna wtadza i nagie życie, przeł. M. Salwa, posł. P. Nowak, Warszawa 2008). Polecam tutaj szczególnie moje wystąpienie pt. Ciato jako polityczna stawka na konferencji „Polityka bez ideologii?”, IV edycja Akademii Politologicznej Politeja.pl (UMK Toruń, 11-12 marca 2010 r.)..

9 Warto w tym kontekście wskazać ciekawą argumentację Gauthiera na temat relacji panujących pomiędzy aksjomatami utylitaryzmu a kontraktualizmu. Zob.: D. Gauthier, David Hume, Contractarian, „The Philosophical Review” 1979, Vol. 88, nr 1, s. 3-38. Autor przekonuje, że cały utylitaryzm można by w gruncie rzeczy sprowadzić do kontraktualizmu, jako że zasadę uprawnienia naturalnego fundament kontraktualizmu, należy interpretować właśnie jako wyraz interesu jednostki. W takim razie utylitaryzm byłby podobną refleksją, z tym że uplasowaną o stopień wyżej, ponieważ na poziomie społeczeństwa. Utylitarysta rozważa przede wszystkim dobrobyt / jakość życia (well-being) jako warunek konieczny, który muszą spetniać regulacje dotyczące wtasności. Z kolei kontraktualista rozwa$\dot{z} a$ korzyśćldobrobyt (well-being) każdej jednostki jako konieczny warunek tego typu regulacji (tamże, s. 9-10). 
poruszonej na kartach Lewiatana. Dyskusji, która toczyła się zarówno na łamach kilku ważnych angielskich czasopism, takich jak „The Journal of Philosophy”, „Law and Philosophy”, „Philosophical Perspectives”, „Noûs”, „Political Theory” czy „The Philosophical Review", jak też przybierała formy całościowych monografii na ten temat. Debata ta trwała od końca lat 60. do końca lat 80., głównie między Jean Hampton, Davidem Gouthierem a Gregorym S. Kavką, ale pojawiły się także inne wartościowe głosy (warto tutaj wymienić np. Kirscha Hoekstrę).

W drugiej zaś części naszej pracy chcielibyśmy przedstawić jeszcze dwa naszym zdaniem niepodnoszone dotychczas argumenty przeciw sytuacji umowy i kontraktualizmowi w ogólności.

\section{I}

David Gauthier, analizując sytuację politycznego wątpienia - jak nazwaliśmy ją w naszym wcześniejszym artykule ${ }^{10}$ - głosi peany na temat politycznego geniuszu i przenikliwości autora Lewiatana ${ }^{11}$, zaliczając go jednocześnie jako pierwszego filozofa do kręgu filozofii decyzji czy, jak to jest częściej ujmowane, do kręgu teorii racjonalnego wyboru. Od razu czyni on z Hobbesa także oryginalnego myśliciela, który wynalazł trzecią drogę pomiędzy powszechnym egoizmem, charakterystycznym dla stanu natury ${ }^{12}$, a indywidualnym altruizmem ${ }^{13}$. Tym, co stanowiłoby fundament racjonalnego wprowadzenia do moralności, miałaby być moralność konwencjonalna, a więc twierdzenie - wyinterpretowane z Hobbesa (a konkretnie z omawianego cały czas fragmentu) - że przestrzeganie reguł jest opłacalne samo w sobie, niezależnie od ich treści.

\section{Gra w moralność}

W tym ujęciu sprawiedliwość to tyle, co przestrzeganie prawa, a więc opłaca się być sprawiedliwym, ponieważ tylko przestrzegając prawa, możemy liczyć na to, że inni, przestrzegając go na równi z nami, zrealizują w ten sposób n a s z cel, jakim jest samozachowanie, a w konsekwencji pokój i dobrobyt ${ }^{14}$. Zarówno tutaj, jak i w innym miejscu ${ }^{15}$ Gauthier interpretuje ową sytuację w kategoriach dylematu więźnia. Macierz wspomnianej sytuacji przedstawia następująco:

10 Warte nadmienienia jest, że mowa tutaj o fragmencie z Lewiatana. T. Hobbes, Lewiatan, czyli Materia, forma i wtadza państwa kościelnego i świeckiego, przeł. Cz. Znamierowski, Warszawa 1954, Biblioteka Klasyki Filozofów. Mowa o fragmencie rozpoczynającym się w polskim tłumaczeniu od słów: Cztowiek szalony powiedziat sobie... (I, XV, s. 127) - do końca s. 129.

11 D. Gauthier, Thomas Hobbes. Moral Theorist, „The Journal of Philosophy” 1979, Vol. 76, nr 10, s. 547.

12 Naturalne zwiazki ludzkie sa catkowicie determinowane przez to, co można, nie zaś przez to, co należy, i to w konsekwencji prowadzi do konfliktu (tamże, s. 549).

13 Tamże, s. 552.

14 Tamże, s. 555-556.

15 Tenże, Morality and Advantage, „The Philosophical Review” 1967, Vol. 76, nr 4, s. 460-475. 


\begin{tabular}{|c|c|c|c|}
\hline & \multicolumn{3}{|c|}{ B } \\
\hline
\end{tabular}

Zdaniem Gauthiera to właśnie odkrycie Hobbesa jest fundamentem pogodzenia korzyści własnej z moralnością, która - dodajmy, a co wynika z kontekstu - utożsamiana jest po prostu z jakąś formą poświęcenia (altruizmu).

$\mathrm{Z}$ pewnością niewiele można zarzucić wywodom Gauthiera. Być może z tym wyjątkiem, iż niczego one nie dowodzą, ponieważ nie są argumentami w sporze z Hobbesem. W innym miejscu stanowisko to Gregory S. Kavka nazywa maksymalizacją ograniczoną ${ }^{16}$, a definiuje w odróżnieniu od maksymalizacji nieograniczonej. To pierwsze stanowisko dąży więc do realizacji egoistycznych celów przy zachowaniu podstawowych ograniczeń. Jest ono rzekomo korzystniejsze, ponieważ wprowadza czynnik zaufania dla wzajemnej wymiany czy współpracy. W ten sposób - należy rozumować - mamy do czynienia zawsze z jakąś wartością dodaną lub przynajmniej z usprawnieniem współpracy ${ }^{17}$.

Problem polega jednak na tym, że taka argumentacja jest trafna jedynie w sytuacji, w której wymiana sama została już przesądzona lub jest pewna w przyszłości, nie zaś w sytuacji ustanowienia pierwszej metakonwencji, która warunkuje inne konwencje. W omawianych przez Gauthiera i Kavkę przykładach faktem jest, że zaufanie nie tylko usprawnia wymianę czy ją przyspiesza, lecz może nawet dla niektórych stron nieść dodatkową korzyść w postaci pewnych nadwyżek dóbr. Jednak tego typu argumentacja zupełnie chybia w przypadku dylematu więźnia, gdzie korzyść jest tym większa, im szybciej dochodzi do zerwan ia współpracy.

Gregory S. Kavka, podobnie jak Gauthier, analizuje daną sytuację w kategoriach dylematu więźnia, z tym że robi to dokładniej ${ }^{18}$, a przede wszystkim zachowując właściwe proporcje, naszym zdaniem zaburzone w macierzy Gauthiera ${ }^{19}$. W jego ujęciu macierz prezentuje się tak:

\begin{tabular}{|c|c|c|c|}
\hline \multicolumn{3}{|c|}{ B } \\
\hline
\end{tabular}

16 G.S. Kavka, The Rationality of Rule-Following. Hobbes's Dispute with the Fool, „Law and Philosophy” 1995, Vol. 14, nr 1, s. 13-14.

17 Tamże.

18 Zob.: tenże, Hobbsian Moral and Political Theory, Princeton 1986, s. 126-141.

19 Być może dlatego, że Gauthier nieco automatycznie i pochopnie utożsamił sytuację z Lewiatana z sytuacją wzajemnego rozbrojenia. 
Ujęcie to zdecydowanie lepiej oddaje sytuację stanu natury. Strona „naiwna” bowiem w przypadku niedotrzymania umowy przez drugą stronę może naprawdę wiele stracić (łącznie z życiem), czego zdaje się nie zauważać Gauthier, który nazbyt chyba optymistycznie ją analizuje. Ponadto, w przypadku wzajemnego zerwania strony ani nic nie zyskują (żadnej stabilizacji), ani też niczego nie tracą, jako że pozostają w stanie natury (dlatego wartości 0, 0 zdecydowanie lepiej odzwierciedlają sytuację po wzajemnym zerwaniu umowy niż - nieco abstrakcyjne - 3,3).

Pomimo drobnych korekt Kavka idzie jednak zasadniczo tropem Gauthiera, podkreślając, że jego stanowisko jest via media (pomiędzy Gauthierem a Jean Hampton). Nie warto ryzykować ostracyzmu społecznego w imię niepewnego zysku, jak ujmuje to sam autor: Najbardziej racjonalnym stanowiskiem jest pozostanie naśladowca norm moralnych spoteczeństwa w przeważającej większości przypadków, jednak mając zawsze w pamięci by skorzystać w przypadku nadarzających się szczególnych okoliczności, w których okaże się niezwykle korzystnym ztamać zwykle przestrzegane zasady ${ }^{20}$.

Pomijając oczywiście już sam fakt moralnej aberracji, jaką niesie za sobą zasada „złotej szansy" ${ }^{21}$, należy przede wszystkim wskazać fundamentalną kolistość tego sposobu rozumowania, i to na dwóch poziomach: (1) w sytuacji stanu naturalnego nie ma mowy o ostracyzmie społecznym, w tym sensie rozumowanie takie zakłada to, co dopiero miało dowieść; (2) po drugie zaś przestrzeganie zasad jest związane z niedoskonałością epistemologiczną człowieka, nie zaś na odwrót. Gdyby człowiek wiedział dokładnie, co jest ową „złotą okazją", i znał wszystkie konsekwencje swoich działań, to pewnie w ogóle nie potrzebowałby praw.

\section{Charakter legitymizacji}

Od prób obrony Hobbesa zdecydowanie dystansuje się Jean Hampton, pisząc, że tego typu argumentacja jest obarczona fundamentalnymi - nieprzezwyciężalnymi, sprzecznościami ${ }^{22}$. Albo prawo natury obowiązuje w stanie natury i zgodnie z nim należy przestrzegać zasad, a wtedy sytuacja umowy jest czystą formalnością, albo nie obowiązuje i wtedy nie ma możliwości, by ktoś nas przekonał do przestrzegania umów, skoro nikt inny ich nie przestrzega ${ }^{23}$. Albo posiadam uprawnienie naturalne i umowa polega na przekazaniu go jednej osobie, której tożsamość automatycznie likwiduje chaos stanu natury ${ }^{24}$, albo go nie przekazuję, co daje mi tym samym prawo do permanentnej oceny

20 Tenże, The Rationality of the Rule-Following..., s. 26.

21 Tamże, s. 28.

22 J. Hampton, Hobbes and the Social Contract Tradition, s. 72.

23 Tamże, s. 73. Jeśli przyjrzeć się argumentacji Hobbesa z tej perspektywy, widać, jaką trudność nastręcza inkorporowanie logicznego porządku warunków możliwości danego zjawiska w porządek czasowy. Co jest właśnie przyczyną zarówno tak wyeksponowanego momentu kontraktu, jak i całej sytuacji wątpienia politycznego. Pod tym więc jedynie względem miałby akurat rację np. Robert Nozick, optując za rozwiązaniem procesualnym. Zob.: R. Nozick, Anarchy, State, and Utopia, New York 1974, s. 10-24.

24 Tamże, s. 119. 
suwerena ze względu na realizację mojego samozachowania; co czyni Hobbesa teoretykiem rewolucji, a Lewiatana „katechizmem rebelii”25.

Być może w tym miejscu warto zarysować różnicę w argumentacji pomiędzy nami a Hampton. Jej tok myśli koncentruje się na sprzeczności pomiędzy zrzeczeniem się uprawnienia do samozachowania, które ufunduje władzę absolutną, a twierdzeniem Hobbesa, że zrobić tego nie można. Podczas gdy nasza argumentacja jest jeszcze poziom niżej, samo bowiem uprawnienie jest już tak zdefiniowane, że na poziomie logicznym wyklucza możliwość przekazywania. Jest to o tyle ważne, że przeciwko zarzutom Hampton można znaleźć kontrargumenty. Niezwykle subtelnie robi to Gauthier, który pisze wprost, że to nie ja uprawniam suwerena do zabicia mnie, gdy kierując się własnym samozachowaniem, złamałem prawo, lecz każdy inny uczestnik umowy. I tak jest w każdym przypadku ${ }^{26}$. Naszych jednak zarzutów ta argumentacja w ogóle nie dotyka.

W kontekście zasady wzajemności należy podkreślić jedną bardzo ważną rzecz: nie może ona być w żaden sposób wydedukowana z egoistycznego samozachowania, ponieważ z niego wyniknąć może co najwyżej twierdzenie, iż gdy w s z y s c y będą przestrzegać prawa natury, to w jakimś stopniu przyczyni się to do moj e go samozachowania, nie zaś - i w gruncie rzeczy nie wiadomo, skąd w ogóle mogło się to wziąć w tak naturalistycznej antropologii - gdy ja będę przestrzegać prawa natury, to przyczyni się to do tego, iż inni będą go przestrzegać. Jest to bardzo ważne, ponieważ ukazuje fundamentalne pomieszanie porządków w myśli Hobbesa: kategoria ,ja” nie jest kategorią filozoficzną, lecz jedynie moralną, podobnie jak samozachowanie jest kategorią moralną, ewentualnie biologiczną. Jako pierwsze jest niejasna, jako drugie zaś - czyli jako własność nazywana instynktem u zwierząt - tak wąska, że natychmiast czyni bezsensowną całą tę koncepcję, nie tylko wyklucza bowiem sytuacje racjonalnego działania, lecz prawdopodobnie w ogóle uniemożliwia poznanie. Wszystkie te kwestie podejmiemy poniżej w części drugiej.

\section{Zwierzę i egoista}

W kontekście całkowitego wyzbycia się uprawnienia naturalnego należy nadmienić krytykę Kavki, że Hampton popełnia błąd, upierając się przy całkowitym przeniesieniu uprawnienia. Wynika to zdaniem autora z przypisywania egoistycznym jednostkom stanu natury zbyt mocnej racjonalności typu wet-za-wet, podczas gdy nie jest sprzecz-

25 J. Hampton, The Failure of Hobbes's Social Contract Argument, [w:] The Social Contract Theorists. Critical Essays on Hobbes, Locke and Rousseau, ed. Ch.W. Morris, Maryland 1999, s. 44.

26 D. Gauthier, The Logic of Leviathan. The Moral and Political Thought of Thomas Hobbes, Oxford 1969 , s. 148. Jest to z pewnością niezwykle inteligentny i ważny argument, który likwiduje oczywistą sprzeczność z teorii Lewiatana, w żadnym razie bowiem nie wymaga od nas zrzeczenia się uprawnienia do samozachowania. Problem polega jednak na tym, na ile jest on ważny dla uzasadnień kontraktualnych. Czy nie jest bowiem tak, że choć nie zrzekam się explicite uprawnienia, to jednak, podpisując umowę, podejmuję działania, które uniemożliwią mi korzystanie z niego. Jest to więc argument ważny dla teoretyka i obrońcy Hobbesa, nie przekonałby on jednak prawdziwego egoisty w sytuacji podpisywania umowy, z prostej przyczyny - w stanie natury porządek legalny nie istnieje, liczą się jedynie fakty. 
ne $\mathrm{z}$ istotą stanu natury przypisanie im nieco słabszej racjonalności, np. wet-za-dwa wety $y^{27}$. Podobnie Gauthier nie może zrozumieć Hampton, która zbyt mocno jego zdaniem rozdziela zgodę od umowy. Zgoda nie jest żadną gwarancją, a umowa gwarancją zbyt mocną. Gauthier uważa, że to błąd, ponieważ Hampton zakłada jedynie sytuację, w której albo realizujemy swoje egoistyczne popędy (zgoda będzie instrumentem, a więc traci jakiekolwiek walory stabilizujące), albo ich się zrzekamy na rzecz innego podmiotu, który będzie realizował teraz własne egoistyczne cele z użyciem wszystkich członków kolektywu. Gauthier argumentuje, że jest przecież jeszcze sytuacja wzajemnej koordynacji egoistycznych popędów, a więc całkiem namacalna sytuacja liberalnego społeczeństwa ${ }^{28}$. I takie podejście właśnie definiuje zdaniem Gauthiera rolę, jaką w całym systemie miałby odgrywać suweren ${ }^{29}$; wiąże się to jednocześnie z interpretacją pozwolenia jako legitymizacji bez alienacji ${ }^{30}$.

W ten sposób wchodzimy w sam środek kwestii kluczowej dla naszych rozważań, który wiąże problem wiedzy z problemem etycznym. Gauthier nie ma w tym sporze racji z dwóch powodów.

Po pierwsze, dziwne samo w sobie jest założenie, iż jest możliwa koordynacja egoistycznych celów bez istotnego ich ograniczenia, tym jednak dziwniejsze, iż mówimy o całkowicie mechanicznej antropologii Hobbesa. W tym kontekście Hampton ma bezwzględnie rację, interpretując stan natury zgodnie z naturalistyczną wizją natury ludzkiej ${ }^{31}$, która, gdy analizować ją zgodnie z założeniami, w ogóle ma problem z choć-

27 Zob.: G.S. Kavka, The Rationality of the Rule-Following..., s. 13.

Zob.: D. Gauthier, Symposium Papers, Comments and an Abstract. Hobbes's Social Contract, „Noûs” 1988, Vol. 22, nr 1, s. 71-82.

Tenże, Hobbes's Social Contract, [w:] The Social Contract Theorists..., s. 62.

30 Tamże, s. 69.

31 J. Hampton, Hobbes and Social Contract Tradition, s. 18-22. Warto przy tej okazji wspomnieć ciekawy artykuł Hampton dotyczący fundamentalnych sprzeczności w próbie pogodzenia naukowego poglądu na cztowieka z jakąkolwiek dozą racjonalności w filozofii Hobbesa (zob.: J. Hampton, Hobbes and Ethical Naturalism, „Philosophical Perspectives” 1992, Vol. 6, s. 333-353): Subiektywizm w swej istocie jest stanowiskiem, które w sporze o status ludzkich wartości wystrzega się metafizycznego „nonsensu". To, co jest odpowiedzialne za nasze oceny $i$ co popycha nas do dziatania, nie jest rodzajem tajemniczego wewnętrznego dobra "gdzieś tam", lecz naszymi pożądaniami, których zaspokojenie jest osiagane poprzez zabezpieczenie przedmiotów, w których mocy jest zaspokoić nasze pożądania - to nazywamy dobrem (tamże, s. 336). Teoria Hobbesa stara się zatem zachować normatywność moralnych imperatywów, lecz wyjaśnić je jako coś skonstruowanego w catości ze sktadników nie-normatywnych (s. 338). Nie przytaczamy tych cytatów jedynie, by poszerzyć perspektywę, lecz po to, by dokładnie wyjaśnić, iż teoria Hobbesa jest sprzeczna nie dlatego, iż redukuje normatywność świata ludzkiego, lecz dlatego, że nie są w niej w ogóle możliwe wiedza, poznanie i w ogólności nauka, a więc to wszystko, co zapewniło jej swego czasu taki rozgłos. Zgodnie bowiem z teorią Hobbesa należy w ludzkim działaniu zrezygnować z teorii teleologicznych, a wprowadzić teorie kauzalne (tamże, s. 339). To nie bowiem nakierowanie na przedmiot pobudza nas do działania (to wymaga rozpoznania), lecz pożądanie - mechanizm pozaracjonalny. Dlatego ta teoria jest tak mocna, iż uniemożliwia wprowadzenie jakichkolwiek zapośredniczeń, gdyż te implikowałyby sprzeczność, jako że w takich sytuacjach nie pożądanie by nami kierowało, lecz świadomość większej przyjemności. Doskonale ujmuje to Hampton: Wierzymy więc, że czynność A jest środkiem do jakiegoś celu B, więc jeśli chcę B, powinienem także chcieć A, lecz skąd się tutaj bierze stowo „powinien” (tamże, s. 348). Nie jest to, rzecz jasna, nic nowego, wręcz przeciw- 
by elementarnym zapośredniczeniem działania w rozpoznaniu. Zgodnie bowiem z tą koncepcją poznanie nie ma w ogóle nic wspólnego z naszym działaniem, które jest zawsze powodowane pożądaniem. A sytuacja koordynacji egoizmów wymaga istotnego ich ograniczenia, co w konsekwencji prowadzi do ograniczenia działania, a to z kolei do ograniczenia uprawnienia naturalnego. Zgodnie z rozumowaniem Gauthiera bowiem, jeśli zawsze chcę samozachowania, to winienem chcieć przede wszystkim kooperacji, ponieważ ona samozachowanie gwarantuje. Problem w tym, że nawet na tego typu cesję nie ma miejsca w teorii Hobbesa, gdyż znaczyłoby to, że to, co nami powoduje, to już nie pożądanie, lecz rozpoznanie tego, co do realizacji owego pożądania prowadzi, a przecież rozum nie może wpływać na nasze czyny ${ }^{32}$.

Gauthier mógłby w tym miejscu argumentować, iż nie jest on przecież przeciwnikiem ograniczania samozachowania, a jedynie zwolennikiem jego uzgodnienia (koordynacji). Widzimy więc, że cała wieloznaczność zawiera się w słowie „ograniczać”. Na pozór całe rozumowanie Gauthiera wydaje się poprawne, ponieważ używa on równie wieloznacznego słowa „uzgodnić”, które nasuwa skojarzenie z jakimś uporządkowaniem i rozgraniczeniem. Na przykład poprzez sytuację, w której osoby potrzebujące jakichś przedmiotów w mniejszym stopniu zrzekną się ich na rzecz osób, upatrujących akurat głównie w nich swego samozachowania i na odwrót. Nic bardziej błędnego. Tego typu interpretacja $\mathrm{w}$ ogóle nie bierze pod uwagę, że pożądania są mechaniczne, a więc nie tylko nieuzgadnialne, ale w znacznym stopniu w ogóle niepoznawalne. Po raz kolejny więc przesłanka uzasadniająca moralnie umowę społeczną czyni ją jednocześnie niespójną logicznie.

W ten sposób dwa podstawowe tematy godne rozważenia w części drugiej prezentują się następująco:

a) skąd pomysł, że moje dotrzymanie umowy w jakikolwiek sposób zwiększa moje szanse na przeżycie,

b) w jakim stopniu koncepcja Hobbesa byłaby możliwa jako obrona racjonalności instrumentalnej (jako szerszej niż biologiczna, mechaniczna wizja samozachowania), która prowadzi do wspólnego dobrobytu; a więc interpretacji ahistorycznej.

Poza tym interpretacja Hobbesowskiego suwerena w kierunku liberalnego rządu ma - zdaje się - jeszcze mniej sensu ${ }^{33}$ niż robienie z Hobbesa rewolucjonisty. Michael Goldsmith przekonuje na przykład, że jakakolwiek podzielność suwerenności, koniecz-

nie - to raczej klasyczna wykładnia Hobbesa, którą szli tacy filozofowie z początku wieku, jak Alfred Taylor (zob.: A.E. Taylor, Ethical Doctrine of Hobbes, „Philosophy” 1938, Vol. 13, nr 52, s. 406-424), Harold Warrender (H. Warrender, The Political Philosophy of Hobbes, Oxford 1959, s. 57-58, 87-93, 222-223) czy Michael Oakeshott (M. Oakeshott, Introduction to Leviathan, Oxford 1949, s. LVIII-LXI). L. Strauss, The Philosophy of Hobbes, Chicago 1963, s. 2-25.

32 Zob.: T. Hobbes, Elementy filozofii, t. 1, przeł. Cz. Znamierowski, Warszawa 1956, s. 13-14, Biblioteka Klasyków Filozofii. Sam zresztą Gauthier w swojej monografii wprost pisze, iż dla Hobbesa zdanie: to jest dobre, oznacza jedynie: to jest przedmiot mojego pożaddania (D. Gauthier, The Logic of Leviathan..., s. 8).

33 Poglądu takiego broni np. także Deborah Baumgold (Hobbes's Political Theory, Cambridge 1988). 
na w liberalnej interpretacji, jest z istoty sprzeczna z suwerennością, a szczególnie z suwerennością u Hobbesa; nie chodzi bowiem o państwo suwerenne, lecz o osobowego suwerena $^{34}$. W gruncie rzeczy jednak przytaczany w tym miejscu argument jest znacznie silniejszy, ponieważ wykorzystuje Hobbesowskie rozumowanie z regresu, które jest wykorzystywane, by rozprawić się z ustrojami ograniczonymi ${ }^{35}$.

\section{Hobbes - odpowiedzialny sofista}

Kolejnym zdecydowanym obrońcą spójności konceptualnej teorii umowy społecznej Hobbesa jest Stuart M. Brown jr. Przedstawia spójną i przejrzystą linię obrony Hobbesa przeciw takim klasykom, jak Taylor, Oakeshott czy Warrender ${ }^{36}$. Jest to dość specyficzna argumentacja, którą można podsumować w tych słowach: wskazani autorzy zbyt serio wzięli Hobbesa. Nie był on bowiem filozofem par excellence, a jedynie doktrynerem politycznym zatroskanym o los swojej ojczyzny, dlatego jego tekst nie powinien być analizowany jako prawdziwy obraz rzeczywistości, lecz jedynie jako spójna i logicznie niesprzeczna argumentacja, wyprowadzająca moralne zobowiązania z naturalnych inklinacji; interpretacja taka ponadto zgodna by była $\mathrm{z}$ historycznym kontekstem ${ }^{37}$. Możemy tutaj zaprezentować skróconą wersję tego rozumowania ${ }^{38}$ :

1. Ludzie dążą do uzyskania odpowiednich przedmiotów, a unikają innych. Różni ludzie dążą do różnych rzeczy, jakkolwiek nawet ten sam człowiek w tym samym czasie może dążyć do wielu rzeczy.

2. Te rzeczy, do których człowiek dąży, zwiemy dobrymi, a te, których unika, złymi.

3. Moc (władza) jest tym, co umożliwia człowiekowi dążenie do upragnionych dóbr.

4. Ludzie są więc równi pod względem władz naturalnych, choć różnią się względem władz nabytych.

5. Brak rządu jest nazywany - stanem natury.

34 M.M. Goldsmith, Hobbes's „Mortal God”. Is There Fallacy in Hobbes's Theory of Sovereignty?, [w:] The Social Contract Theorist..., s. 29. Argumentacja [Hobbesa] jest absolutystyczna $i$ anty-konstytucyjna, Hobbes i inni wyprowadzili swoje wnioski doktadnie stad, iż mieszana suwerenność lub jakaś liczba oddzielonych jednostek i organizacji posiadających suwerenność tacznie lub procedury prawne, lub zestaw takich procedur jako suwerenność, są niemożliwe (tamże).

J. Hampton, Hobbes and the Social Contract Tradition, s. 103-104.

36 S.M. Brown Jr., Hobbes. The Taylor Thesis, „The Philosophical Review” 1959, Vol. 68, nr 3, s. 303-323.

37 Tamże, s. 311-312. Podstawowym pytaniem, jakie stoi przed Hobbesem, nie jest prima facie wcale pytanie filozoficzne. Jest nim pytanie o moralna i obywatelska roztropność, jak ustanowić konkretne obowiąki bezwarunkowego postuszeństwa wtadzy państwowej (tamże, s. 315). Quentin Skinner przytacza dość poważne argumenty za tego typu argumentacją, na przykład wbrew twierdzeniom Hampton, iż Hobbes w oczywisty sposób zdecydowanie popierał reżim Olivera Cromwella. Zob.: Q. Skinner, Conquest and Consent. Thomas Hobbes and the Engagement Controversy, [w:] The Interregnum. The Quest for Settlement, 1646-1660, ed. G.E. Aylmer, London 1972, s. 80.

38 W oryginale zajmuje ono prawie cztery strony. Zob.: S.M. Brown Jr., Hobbes. The Taylor Thesis, s. 316-319 . 
6. Jedynymi prawami, jakie ustanawiają warunki konieczne, by wszyscy osiągnęli własne dobra, dookreślając akty równe dla wszystkich, jeśli te warunki zostaną spełnione, są prawa natury. Może nim być na przykład pokój.

7. Podstawowym warunkiem pokoju jest to, by każdy człowiek zszedł z drogi innemu i zostawił go w spokoju i bezpieczeństwie.

8. Moralną praktyką, dzięki której ludzie zasadniczo zdobywają swe dobra, jednocześnie względnie zapewniając dobra innym, są umowy ${ }^{39}$.

Nie wiadomo dlaczego rozumowanie to błędnie zakłada, że różni ludzie dąża do różnych dóbr. Zgodnie bowiem z wąską interpretacją samozachowania bardziej prawdopodobne wydaje się, że instynkt wskazywałyby ludziom te same przedmioty jako warunek samozachowania (na przykład wielu osobom na danym terenie kazałby walczyć o jedyną dostępną jaskinię). Zgodnie jednak z wcześniejszymi wnioskami literalne czytanie Hobbesa wydaje się mało ciekawe ${ }^{40}$. Dlatego uznajemy tu za stosowne skupienie się na interpretacji Hobbesa jako obrońcy racjonalności instrumentalnej, tzn. takiej, która - pomijając już pewne uściślenia, jakie podejmiemy zasadniczo dopiero w części drugiej - dopuszcza istotne manipulowanie naszymi pożądaniami (na przykład oddalanie ich zaspokojenia $\mathrm{w}$ czasie lub łączenie ich zaspokojenia z innymi czynnościami, które nie są z nim fizycznie powiązane).

Okazuje się jednak, że i przy tej interpretacji niepodobna uniknąć konfliktów, unikamy bowiem jedynie konieczności wojny, nie wykluczając jednak możliwości konfliktu. Do tego należałoby - i takim tropem zdaje się podążać autor - zaangażować jakieś niezwykłe środki zaradcze w postaci na przykład „niewidzialnej ręki” przyporządkowującej ludziom pożądania (na przykład niezwykle rozbudowana reklama lub jakieś państwo opiekuńczo-motywacyjne). Nie widać więc żadnej możliwości, by sytuacje opisywane przez tezy nr 1 i 7 nie wchodzily ze sobą w permanentny konflikt ${ }^{41}$.

Zostawiając kwestię jakości korzyści, rozważmy jeszcze ich ilość. To rozumowanie byłoby prawdziwe, gdyby było pewne, iż każdy bez wyjątku dostanie po podpisaniu

\section{Tamże, s. 319.}

40 Mało ciekawe, ponieważ prowadzi do sprzeczności. Ciekawą natomiast analizą jest próba wydobycia informacji, jak naczelne materialistyczne założenia antropologiczne zdeterminowały późniejsze treści polityczne. Zob.: J. Hampton, Hobbes and the Social Contract Tradition, s. 18-36. Autorka doskonale dowodzi, w jaki sposób monizm psychologiczny implikuje egoizm, który z kolei skutkuje w tezie o egalitaryzmie.

${ }^{41}$ W gruncie rzeczy widać tutaj podstawowe niebezpieczeństwo porządku liberalnego, który ufundowany jest na pożądaniu dóbr. Stąd warunkiem niezbędnym tego systemu jest nieskończona podaż dóbr - zawsze większa od popytu, w przeciwnym razie bowiem natychmiast mamy do czynienia z poważnym konfliktem. By pomieścić bezkonfliktowo wszystkie jednostki w jednej przestrzeni, musi on nie tylko dostarczać nieskończonej ilości dóbr, lecz także zapewnić heterogeniczność sposobów ich osiągania. To twierdzenie stałoby w sprzeczności z wizją „niewidzialnej ręki”, oznaczałoby ono bowiem, iż liberalizm, lub przynajmniej powszechnie rozwinięty liberalizm, jest nierozerwalnie związany z biurokracją. Twierdzenie to byłoby o tyle ciekawe, iż tłumaczyłoby mariaż socjalizmu i liberalizmu po drugiej wojnie światowej nie jako przygodny, lecz konieczny - wynikający z samej logiki porządku liberalnego. Zob.: M. Podniesiński, Symulacja spoteczeństwa europejskiego, [w:] Politikon III. Kto jest suwerenem?, red. M. Rysiewicz, M. Podniesiński, M. Burzyk, Kraków 2011. 
umowy więcej nie tylko relatywnie do stanu natury, co jest prawdopodobniejsze, lecz także względem innych członków społeczeństwa, co z kolei jest logicznie sprzeczne ${ }^{42}$.

\section{Hobbes jako pierwszy postmodernista}

Jedną z najciekawszych i naprawdę oryginalnych interpretacji Hobbesa przedstawił Kirch Hoekstra ${ }^{43}$. Podszedł on do tego fragmentu zupełnie inaczej, przyjmując perspektywę, którą realiści polityczni nazywają prymatem perspektywy politycznej, czyli w skrócie - uznał za prymarną relację władzy. Zdaniem Hoekstry Hobbes nie jest naiwny i wcale nie wycofuje się ze swojej egoistycznej antropologii, ponieważ jego argument jest w gruncie rzeczy niezwykle pragmatyczny, a przy tym teologiczny.

Hoekstra zauważa, że Hobbes, pisząc słowa: cztowiek szalony powiedziat sobie w swym sercu, iż nie ma sprawiedliwości..., w gruncie rzeczy powołuje się na Psalm 14, który zaczyna się od słów: Mówi gtupi w swoim sercu: „nie ma Boga”ł. Hoekstra zupełnie zmienia wydźwięk tego fragmentu, czyniąc z Hobbesa raczej „sprytnego kaznodzieję" niż politycznego teoretyka ${ }^{45}$. Ten argument jest ważny dlatego, że w pełni harmonizuje z duchem purytanizmu, który nie wierząc w rozum oraz radykalnie postponując ludzką racjonalność, był niezwykle skory do narzucania społeczeństwu surowych norm o charakterze ascetycznym.

42 Niemożliwe bowiem, by wszyscy dostali więcej. Tego w szczególności zdają się nie dostrzegać kontraktualiści. Stan natury, podobnie jak bezprawie, po ustanowieniu kontraktu będzie się niezwykle opłacał osobnikom posiadającym bądź to walory czysto fizyczne (siła), bądź inne środki umożliwiające podporządkowanie sobie innych względnie bezpośrednio (np. prywatna armia). Pod tym względem jest to poważny zarzut o genetyczną nierealistyczność teorii kontraktu, nie w takim sensie, w jakim o realizmie mówią tzw. realiści polityczni, lecz w tym znaczeniu, że podstawowym założeniem teorii kontraktu jest brak lub nawet niemożność rozpoznania swojej pozycji i relacji, w jakich się znajdujemy w społeczeństwie. (Tu po raz pierwszy zahaczamy o teorię Johna Rawlsa. Czy ktokolwiek gdziekolwiek widział człowieka, który podpisze umowę bez rozpoznania jej konsekwencji? Zob.: J. Rawls, Teoria sprawiedliwości, przel. M. Panufnik, J. Pasek, A. Romaniuk, Warszawa 1994, s. 31 i nast., Biblioteka Wspótczesnych Filozofów). Takim osobom trzeba by było zapewnić jakieś specjalne warunki, by zechciały przystąpić do traktatu, a to z kolei naruszałoby zarówno postanowienia traktatu (równość wobec prawa), jak i jego sens. (Jest to o tyle ważne, że przechodząc na chwilę na grunt bieżącej polityki, widzimy, iż jest to teoretyczny opis np. sytuacji okrągłego stołu i wydarzeń 1989 r. w Polsce. Wówczas transformację ustrojową uzależniono od specjalnych przywilejów dla dawnych funkcjonariuszy, zarówno tych prawnych: wyłączenie trzech kluczowych resortów siłowych i urzędu prezydenta spod mechanizmów demokratycznych, jak i ekonomicznych związanych ze słynną ustawą Wilczka; zob.: A. Dudek, Historia polityczna Polski 1989-2005, Kraków 2007, Arkana Historii; Z. Krasnodębski, Już nie przeszkadza. Szkice polityczne III, Kraków 2010, s. 15-50, Biblioteka Myśli Politycznej, 73). Widzimy więc dokładnie, jak słabe jest, być może najprostsze, twierdzenie o przyrodzonej równości dyspozycji fizycznych. Po pierwsze jest to nieprawda, po drugie, nawet jeśli przyjęlibyśmy jakieś granice, których nikt nie jest w stanie przekroczyć, to znów nie podobna wskazać granicy interpretacji cech fizycznych. Czy na przykład niezwykłe zdolności oratorskie Hitlera to zdolności naturalne czy nabyte? W świecie ludzkim niepodobna tego stwierdzić.

43 K. Hoekstra, Hobbes and the Foole, „Political Theory” 1997, Vol. 25, nr 5, s. 620-654.

44 Ps 14,1 .

45 K. Hoekstra, Hobbes and the Foole, s. 625. 
Hoekstra reinterpretuje argumentację, wprowadzając konceptualny podział na głośnego (gadatliwego) głupca i głupca cichego.

a) głupiec głośny to ten, który nie dotrzymuje swych umów i się tym pyszni, podczas gdy:

b) głupiec cichy to ten, który wprawdzie ich nie dotrzymuje, lecz nigdy do tego się nie przyzna (jest on więc wyrachowanym hipokrytą).

Hoekstra zauważa rzecz dla nas w tym artykule fundamentalną: niedotrzymywanie umów opłaca się jedynie cichemu głupcowi, nigdy jednak głupcowi głośnemu, jako że ten, podając w wątpienie porządek społeczny, oparty na zasadzie dotrzymywania umów - znosi jednocześnie wa r u n ek swojej korzyści ${ }^{46}$. Jest to więc rozwinięcie konfuzji, w którą wpadliśmy już wcześniej: prawdziwa egoistyczna interpretacja dotyczy wszystkich raczej, na samym końcu zaś nas samych. Hoekstra wydobywa więc kluczową dla debaty „pro-antykontraktualistycznej” różnicę. Nieprzestrzeganie umów opłaca się w sytuacji, gdy inni ich przestrzegają, n i e zaś $\mathrm{n}$ a odwrót, w drugą stronę ten argument z u pełni e zawodzi ${ }^{47}$. Nawet jeśli pojedynczemu się to opłaci, to już nie opłaci mu się o tym mówić. Hoekstrze doskonale udaje się więc wydobyć faktycznie konieczny warunek funkcjonowania społeczeństwa w ogóle i jest to argument zdecydowanie przeciwko Hobbesowi, nie zaś w jego obronie. Nie chodzi więc o to, że zabijając suwerena czy doprowadzając do wybuchu rewolucji, postępuje się nierozsądnie, lecz że konsekwencje tego są nierozsądne, ponieważ likwidując kryterium oceny - narzucone przez suwerena - zdaje się na inne prywatne normy, co w konsekwencji doprowadzi do zmniejszenia własnych zysków, a może ostatecznej porażki.

Stanowisko Hobbesa brzmiałoby więc, że racjonalne nie jest dotrzymywanie umów, lecz jedynie deklarowanie, iż się ich dotrzymuje! $!^{48}$ Jest to o tyle kluczowe, że czyni z Hobbesa prekursora nie tyle modernizmu, naukowości i absolutyzmu, ile postmodernizmu, perspektywizmu i pragmatyzmu. Jest to ponadto interpretacja ważna, ponieważ w znacznej mierze tłumaczy także jedne z najbardziej niezrozumiałych słów $\mathrm{w}$ Lewiatanie: Prawa natury obowiazuja in foro interno; to znaczy: zobowiazuja one do pragnienia, by tak byto, jak one mówia; natomiast nie zawsze obowiazują in foro externo, to znaczy nie zawsze zobowiazuja do tego, by je wprowadzać w czyn. Cztowiek bowiem, który bytby skromny, uprzejmy i który dopetniatby wszystkich swoich przyrzeczeń w takim czasie i miejscu, gdzie żaden inny cztowiek tego nie czyni, wystawitby się tylko na pastwe innych ludzi i sprowadzitby pewna swoja zagtade, co by byto sprzeczne z podstawa wszelkich praw natury $[\ldots]^{49}$.

46 Tamże, s. 627-629. Hobbes jest w stanie utrzymywać, że rewolucja jest gtupia po części, ponieważ integralnie wymaga publiczny osąd $i$ skandaliczne dziatanie. [...] Ponieważ dążac do tego, inni moga uznać, by także do tego dążyć w ten sam sposób, a takie podejście jest sprzeczne z rozumem (tamże, s. 634).

47 Hobbes zastosował go zgodnie z tzw. złotą zasadą, która wydaje się najbardziej intuicyjnym sposobem podchodzenia do sprawy, tak naturalnym, że dotychczas nikt jeszcze nie poddawał jej samej dyskusji. Czy jednak konsekwentny egoista powinien się nią posługiwać?

48 Tamże, s. 638.

49 T. Hobbes, Lewiatan..., I, XV, s. 139. 
Są to więc słowa, które jeśli rozumieć je dosłownie, całkowicie niweczą dorobek Hobbesa, gdyż powiedzieć o prawie moralnym, iż nie zawsze trzeba je stosować, to naprawdę nie powiedzieć nic, gdyż jego istotą jest jego stosowanie, co zresztą zawiera się w samym określeniu, pomijając już nawet tragiczną mechaniczność jego rozumienia.

Ludzie dzielą się więc na tych, którzy przestrzegają umów, i na tych, którzy wiedzą, kiedy należy ich przestrzegać, ponieważ ich przestrzeganie w niczym im nie szkodzi, a kiedy należy je złamać, gdy może im to przynieść zysk. Mamy więc świat ludzi sprytnych i naiwniaków, którzy zawsze przestrzegają prawa. W żadnym razie jednak nie mamy społeczeństwa, co najwyżej subtelny kulturowy podbój. Hobbes w takiej interpretacji to Nietzsche nowoczesnego państwa, nie zaś anglosaski Bodin. Interpretacja Hoekstry jest dość spójna i współgra w pełni z koncepcją Hobbesa (szczególnie zaś z jego psychologią i etyką), czyni go jeszcze bardziej radykalnym, przesuwając go z pozycji naiwnego scjentysty i protestanta (jak chcieli go czytać Warrender, Watkins, Taylor czy Hampton, ale także Gauthier) na pozycję nietzscheańską i ponowoczesną, na miejsce, w którym doskonale wiadomo, iż rozum to jedynie wyraz dominacji.

Jest to interpretacja spójna, z tym że przeczy z kolei wcześniej wspomnianym teologicznym aspiracjom Hobbesa.

\section{II}

W tej części obiecaliśmy zająć się dwoma problemami:

a) kwestią dziwnej argumentacji w sytuacji podpisywania umowy,

b) próbą ahistorycznej interpretacji Hobbesa jako teoretyka racjonalności instrumentalnej.

Najpierw rozważmy to drugie zagadnienie.

\section{Hobbes i racjonalność instrumentalna}

W gruncie rzeczy, pomimo swojej ahistoryczności, jest to znacznie popularniejsza droga interpretacji; zauważmy, że poszli nią wszyscy przywoływani tutaj autorzy poza Hampton, która sumiennie podążała tradycyjną - zresztą historycznie prawdziwszą drogą, akcentującą naukowe aspiracje Hobbesa w antropologii, a jakościowego przejścia upatrując w dużej wadze, jaką przywiązał Hobbes do religii ${ }^{50}$. Dopiero współczesna popularność teorii gier i teorii racjonalnego wyboru znacznie przesunęła interpretację Hobbesa w kierunku pragmatycznym.

50 Jest to fakt zbyt często pomijany, iż prawie połowa Lewiatana jest poświęcona państwu kościelnemu. (W Polsce podkreśla to m.in. Ryszard Legutko). Wydaje się, że należy tutaj dodać jeszcze kilku autorów, którzy zdecydowanie przyznawali prymarność pożądań w perspektywie interpretacyjnej. Zob.: L. Strauss, The Political Philosophy of Hobbes, s. 26-27; W. Wudel, Filozofia strachu i nadziei. Teoria spoteczna Tomasza Hobbesa, Warszawa 1971, s. 130-165; R. Piotrowicz, Od materii Świata do materii Państwa. Z filozofii Tomasza Hobbesa, Kraków 2000. 
Czym miałby być jednak rozum instrumentalny? Nie jest to trudne pytanie. Można na nie odpowiedzieć na gruncie klasycznej antropologii tomistycznej. Jest to wyniesienie do rangi podstawowej władzy rozumu praktycznego, a do rangi cnoty podstawowej, cnoty rozsądku (roztropności). Implikuje to istotne deformacje w rozumieniu człowieka w stosunku do ujęć klasycznych. Przede wszystkim oznacza stały prymat woli i zmysłowych władz pożądawczych nad intelektem, co jest o tyle oczywiste, że intelekt jako taki w ogóle nie jest brany pod uwagę. W pełni harmonizuje to z zapotrzebowaniem teoretycznym widocznym w liberalnym społeczeństwie, a także doskonale współgra z teoriami racjonalnego wyboru; chodzi bowiem o prymarność preferencji względem ich ustalania. To drugie jest zarówno poza obszarem zainteresowania teoretyków, jak i zupełnie na marginesie w społeczeństwie liberalnym, zbudowanym na dogmacie: ja pragnę. Cały więc wysiłek teoretyczny w nauce, jak i wysiłek egzystencjalny w życiu, jest skierowany na owego pragnienia zaspokojenie lub usprawiedliwienie go jako racjonalnego.

W takim ujęciu Hobbes byłby liberałem, który być może poniósł porażkę jako twórca boga śmiertelnego, ale jest niezwykle użytecznym „podtrzymywaczem” istniejącego już ładu. I w takim kontekście wszystkie argumenty, szczególnie Kavki i Gauthiera, są dość trafne. Według takiego rozumowania późnym wnukiem Hobbesa okazywałby się Richard Rorty ze swą naczelną tezą pragmatyczną ${ }^{51}$. Jest to sugestywna, elegancka i bezpieczna teza - na pierwszy rzut oka. Tego typu liberalni pragmatyści wprowadzają do dyskursu wiele nieobecnych do tej pory słów o konotacjach niezwykle pozytywnych: solidarność, współpraca, współczucie, autokreacja, pokój, unikanie krzywd, bezpieczeństwo, dialog, podtrzymywanie rozmowy itd. Przedstawmy pokrótce garść argumentów przeciw temu sposobowi myślenia, jako w jakimś sensie możliwemu do wyinterpretowania z Hobbesa.

Zarzut logiczny: jeśli dajemy pierwszeństwo działaniu przed rozpoznaniem, to czynimy tym samym nasze działanie ślepym, co prowadzi do utraty kryteriów działania. Działanie bowiem zawsze musi być ukierunkowane na cel. Tymczasem pragmatyzm to taki pogląd, który chce nas przekonać do tego, iż pewne działanie jest dobre już samo w sobie. Redukując więc kryteria działania do samego działania, naraża się na niebezpieczeństwo popadnięcia w błędne koło legitymizowania każdego działania. By być pragmatycznym, należy bowiem odpowiedzieć na pytanie, w czym się jest pragmatycznym, a tego większość neoliberalnych myślicieli w ogóle nie czyni.

Zarzut z aktywizmu: na poziomie etycznym ten paradoks generuje poważne egzystencjalne problemy - prowadzi do ślepego aktywizm, który tym więcej energii poświęca działaniu, im mniej jest pewny jego słuszności czy adekwatności; co doskonale widać szczególnie w mikroekonomii ${ }^{52}$.

51 R. Rorty, Pierwszeństwo demokracji wobec filozofii, [w:] tenże, Obiektywność, relatywizm, prawda, przeł. J. Margański, Warszawa 1999, s. 261-291, Pisma filozoficzne, t. 1.

52 Jeśli kogoś sam ślepy aktywizm jeszcze nie odstrasza, to pozwalamy sobie przytoczyć poglądy Hanny Arendt, która charakteryzując nazistów i społeczeństwo niemieckie podczas drugiej wojny światowej, pisze: ludzi tych pociagat zdecydowany aktywizm ruchów totalitarnych, dziwaczny i tylko pozornie sprzeczny nacisk na prymat czystego dziatania i na pewna site zwyktej konieczności (H. Arendt, Korzenie 
Zarzut $\mathrm{z}$ fundamentalizmu: tego typu stanowisko zmierza $\mathrm{w}$ stronę fundamentalizmu kulturowego. Na poziomie politycznym prowadzi bowiem z jednej strony do ślepego naśladowania bądź tego, co było do tej pory (jak w krajach zachodnich), bądź innych, niezależnie od własnego charakteru narodowego (czego doskonałym przykładem jest polska polityka po r. 2007), z drugiej jednak strony może prowadzić do narzucania innym kulturom swoich ,jedynie słusznych poglądów”53.

Zarzut prawny: zarówno Gauthier, jak i Kavka argumentują, że przestrzeganie prawa zawsze się opłaca, ponieważ jest warunkiem przetrwania (jest to w skali mikro klasyczny argument wszystkich liberałów za obecnym porządkiem). Naszym zdaniem to twierdzenie jest błędne, a to dlatego, iż posługuje się metaforą: używa słowa „prawo”, mając na myśli takie prawo, które rzeczywiście umożliwia moje samozachowanie i pokój, a nie prawo w ogóle. Ten banalny błąd powoduje właśnie, iż pragmatyzm może cieszyć się taką popularnością. W gruncie rzeczy bowiem oczywiste jest, że zanim będziemy prawa przestrzegali, musimy drobiazgowo rozpoznać, do jakich prowadzi ono konsekwencji, co czyni cały argument truizmem.

Zarzut moralny: czy naprawdę naszym właściwym horyzontem moralnym jest ślepy konsumpcjonizm, połączony z pozornym kreowaniem swojego wizerunku poprzez realizację doraźnych i przygodnych celów, do czego przekonuje nas Rorty, pisząc o produkowaniu kolejnych opisów człowieka, filozofii budującej ${ }^{54}$ czy lepieniu własnych tożsamości ${ }^{55}$ ? Skąd w ogóle wniosek, iż takie rozlazłe i zanurzone w zaspokajaniu włas-

totalitaryzmu, t. 2, przeł. D. Grinberg, M. Szawiel, Warszawa 2008, s. 63-64). Dalej analizując doświadczenie pokolenia frontowego, autorka pisze o doświadczeniu nieustannej aktywności w ramach przemożnego fatalizmu (tamże). Dlatego gdy czytamy argumenty Rorty’ego, który w przyplywie szczerości pisze wprost, iż polityce należy przyznaćpierwszeństwo, filozofię zaśfastrygując na miarę (R. Rorty, Pierwszeństwo demokracji wobec filozofii, s. 265), to nasuwają się nam natychmiast skojarzenia z przywoływanymi przez Arendt słowami jednego z nazistów: Kiedy przejmiemy wtadze - program zrodzi się $\operatorname{sam}$ (H. Arendt, Korzenie totalitaryzmu, t. 2, s. 203).

53 Szczegółowo ten problem omawialiśmy w innym miejscu (mowa o naszej monografii poświęconej myśli Foucaulta, która jest obecnie przygotowywana do druku) i dlatego tu jedynie go szkicujemy. Jest to oryginalne stanowisko Hilarego Putnama (zob.: H. Putnam, Why Reason Can't Be Naturalized, [w:] tenże, Realism and Reason, Cambridge 1983, s. 237-238), oparte o poglądy Donalda Davidsona, zaś na gruncie polskim niezwykle prosto i przejrzyście ujął to Zbigniew Czernyszewski: Relatywizm kulturowy, negując istnienie ponadkulturowych kryteriów prawdy czy racjonalności może tatwo, jak zauważa Putnam, przeksztatcić sie $w$ kulturowy imperializm. Relatywista może bowiem uznać, że jedynym pojęciem prawdy czy racjonalności, które jest $w$ stanie w petni zrozumieć i którym może postugiwać się efektywnie, jest pojęcie określone przez normy jego wtasnej kultury. Może nie dostrzegać żadnych racji, które miatyby przemawiać za uwzględnieniem pojęć prawdy czy racjonalności określanych przez normy innych kultur. Takie stanowisko nie bytoby już faktycznie relatywistyczne, lecz bytoby wtaściwie stanowiskiem imperializmu kulturowego (Z. Czernyszewski, Rorty'ego wizja nowej filozofii a relatywizm $i$ imperializm kulturowy, [w:] Oblicza postmoderny. Teoria i praktyka uczestnictwa w kulturze wspótczesnej, red. A. Zeidler-Janiszewska, Warszawa 1992, s. 89, Wokót Przetomu Postmodernistycznego).

54 R. Rorty, Filozofia a zwierciadto natury, przet. M. Szczubiałka, Warszawa 1994, s. 320, Biblioteka Altheia.

55 Zaktadam bowiem, że każdemu wolno zmontować taki model „ja”, jaki mu odpowiada, przykrawaí go do wtasnej polityki, religii, osobistego poczucia sensu życia (tenże, Pierwszeństwo demokracji wobec filozofii, s. 273). 
nych pożądań społeczeństwo jest bezpieczne? Wojny nie będzie, bo nikomu nie będzie się chciato jej prowadzić? Wydaje się jednak, że w tego typu argumentacji w ogóle nie bierze się po uwagę rosnącego kosztu rozpędzonych machin konsumpcyjnych, które będą coraz częściej musiały ścierać się o dostęp do surowców i zasobów ${ }^{56}$.

Czy racjonalność instrumentalna jest w ogóle możliwa? To znaczy, jak możliwa jest sytuacja, w której przeważająca większość społeczeństwa nie rozpoznaje swoich celów życiowych? Paradoks polega na tym, że właśnie stan natury (rozumiany jako stan przedpolityczny, nie zaś przedmoralny) byłby doskonałym miejscem do postawienia tego rodzaju pytań, co tym bardziej czyni - co zabawne - racjonalność instrumentalną (a więc - dodajmy - rozszerzoną interpretację samozachowania) nie warunkiem społeczeństwa, lecz jego produktem. Odnajdujemy tu odpowiedź na pytanie o miejsce popkultury i gospodarki usługowej w liberalnym porządku. Ponownie widzimy, że są one z nim nierozerwalnie związane. Znajdujemy kolejny, choć pośredni argument w sporze z Hobbesem: wydaje się, że stan przedpolityczny raczej sprzyja rozpowszechnianiu się diametralnie innych od racjonalności instrumentalnej postaw. Dobrym przykładem wydaje się tutaj wczesne średniowiecze i próba odbudowywania porządku społecznego w oparciu o religię i relacje prywatne. Jest to o tyle istotny argument, że po raz kolejny pokazuje miarę obrócenia logiki u Hobbesa: skąd w ogóle pomysł na umowę wszystkich ze wszystkimi - model prawny chyba najtrudniej realizowalny ze wszystkich dostępnych.

Przykład wczesnego średniowiecza na zachodzie Europy jest o tyle istotny, że wprost przeczy Hobbesowi: po pierwsze w stanie zaniku wszelkich norm odniesienia ludzie sięgają po systemy najwyższego rzędu: religie, przekonania metafizyczne, po drugie zaś realizują oni to, co najłatwiejsze, a więc trwałe relacje z innymi, takie jak relacje seniora $\mathrm{z}$ wasalem, oparte o prawo prywatne, relacje rodzinne, kształtowanie wspólnot lokalnych: gmin, zakonów czy parafii. Tomasz Hobbes wymyślił jednak na odwrót. Sięgnął po najniższe motywacje i najprymitywniejsze prawa, jednocześnie nakazał jednak ludziom wznoszenie najbardziej abstrakcyjnych i wyalienowanych instytucji.

\section{Zasada wzajemności jako produkt inklinacji społecznych}

Podstawowym jednak argumentem i, o ile nam wiadomo, stosunkowo nowym w debacie z Hobbesem jest, co następuje: egoista w stanie natury nie ma prawa sięgnąć nawet po najbardziej ogólną zasadę wzajemności, ponieważ:

a) jest ona sprzeczna $z$ istotą egoizmu (jakkolwiek rozumianego),

b) zakłada wiedzę o podstawowej inklinacji społecznej, jaką jest popęd społeczny.

Sama zasada wzajemności jest zasadą, ściśle biorąc, moralną, postspołeczną. Jeśli się na nią powołujemy jako na argument, to tym samym potwierdzamy, że rozumiemy, na czym polega warunek społeczeństwa: rozpoznanie innego jako drugiego ja!

56 Świat 2025. Scenariusze Narodowej Rady wywiadu USA, przeł. A. Krzynówek, M. Modrzejewska, wstęp J. Staniszkis, Kraków 2009, s. 204. 
Dlatego nie wiadomo, dlaczego zasada ta miałaby się pojawić w świecie przedmoralnym. Na najniższym bowiem poziomie zakłada ona społeczną inklinację, a więc rozpoznanie innego jako innego $j a$. Stąd pomijane więc przez wszystkich płynne przechodzenie od twierdzenia: jak ja będę czynit $A$, to inni też będa czynić $A$. Przeciwnie, w sytuacji podpisywania umowy społecznej interesuje mnie jedynie to drugie. W stanie przedpolitycznym i przedmoralnym (jak chce tego sam Hobbes) w ogóle nie mam prawa rozpoznawać innych jako jakichś ja. Bo niby skąd i dlaczgo?

Jeśli to rozumowanie jest dla nas naturalne - a kilkaset lat dyskusji ukazuje, że jest to dowodzi ono czegoś zgoła przeciwnego niż cały Lewiatan: stan polityczny jest bezwzględnie pierwszy, nie dlatego, że byśmy bez niego nie przeżyli, lecz dlatego, że byśmy nawet nie potrafili bez niego myśleć. W tym sensie stan społeczny jest bezwzględnie transcendentalny, tzn. zakorzeniony w naszej rozumności, czy używając terminologii kantowskiej: stanowiący formę naszego społecznego rozumienia.

Nie jest to prawdą, możemy bowiem wskazać wiele zwierząt, które z pewnością kierują się zasadą wzajemności, np. szympansy wzajemnie się iskają. Odpowiadamy na to, że jak najbardziej - i dlatego właśnie uważamy je za najbardziej rozwinięte - obok nas - ssaki. Poza tym czym innym przecież jest stosowanie danej zasady, a czym innym świadome się na nią powoływanie w myśleniu. Czym innym jest prosta zależność: jak ty zrobisz $A$, to ja także zrobię $A$, a innym ekstrapolacja tego działania na wszystkich uczestników gatunku.

Należy się także pokrótce odnieść do twierdzenia, iż reguła wzajemności jest sprzeczna z zasadą egoizmu. Jest tak dlatego, a czego większość komentatorów nie chce zauważać, że konsekwentny egoizm to nie tylko dbanie o własną korzyść, lecz także myślenie w kategoriach ego (czemu odpowiadałoby pojęcie egocentryzmu). Prawdziwy bowiem egoista powinien w ogóle mieć problem z rozpoznaniem innego jako innego ja. W tym sensie ludzki egoizm jest znacznie silniejszy niż zwierzęce samozachowanie, ponieważ z łatwością wyradza się w sadyzm. Dlatego prawdziwa wizja stanu natury to raczej piwnice zamku markiza de Sade niż kooperacja egoizmów w liberalnym porządku. Ludzki egoizm zatem rozpina się niebezpiecznie pomiędzy instrumentalizmem - gdzie argumentem jest jedynie: postępuj tak, by doprowadzić do tego, by inni przestrzegali prawa, ponieważ to jest dla ciebie korzystne, i co najwyżej, jeśli jest to konieczne, także deklaruj, że je przestrzegasz - a sadyzmem, którego naczelną dewizą jest: zawsze postępuj tak, by inny był dla ciebie jedynie narzędziem, nigdy celem. Ż adna z tych sytuacji nie zmusza nas - co należy podkreślić - do przestrzegania prawa, do tego bowiem - i czynimy to jednocześnie najważniejszą myślą naszego artykułu - potrzebna jest jako konieczna - wspólna wizja natury ludzkiej57.

57 Paradoks polega na tym, że właśnie najłatwiejszą tego rodzaju wizję daje prosty fakt istnienia społeczeństwa, każdy inny wymaga albo założeń metafizycznych, albo transcendentalnych, albo religijnych. Właśnie istnienie tej zasady jest najprostszą drogą do jej zrozumienia. Czym innym jest jednak stosowanie tej zasady lub stosowanie się do niej (społeczności szympansów), a czym innym świadome jej wydobycie i zastosowanie w argumentacji. 
Cały paradoks Hobbesa polega na tym, że właśnie powołując się na złotą zasadę, jednocześnie potwierdza jej istnienie, co stawia go w sytuacji konieczności odpowiedzi na pytanie o wspólne cechy przedstawicieli gatunku ludzkiego, skoro rozpoznaje w ogóle innego jako podobnego do mnie. Podczas gdy w sytuacji prostej konstatacji istnienia społeczeństw nie musiałby się na tę złotą zasadę powoływać!

Społeczeństwu liberalnemu potrzebna jest wspólna wizja natury ludzkiej znacznie bardziej niż społecznościom naturalnym (podobnie jak argumentacja Hobbesa jest mocniejszym dowodem na prymarność społeczeństwa niż wywody Arystotelesa), te bowiem wystarczy, by się do niej stosowały, podczas gdy społeczności liberalne, ufundowane na kontrakcie, nie tylko muszą się do niej stosować (co rzecz jasna robią), ale muszą ją także wydobyć, zrozumieć i zaakceptować, w przeciwnym bowiem wypadku skrajny rasizm, ksenofobia i nowe formy segregacji staną się tylko kwestią czasu.

\section{BIBLIOGRAFIA}

Agamben G., Homo sacer. Suwerenna wtadza i nagie życie, przeł. M. Salwa, posł. P. Nowak, Warszawa 2008.

Agamben G., Stan wyjątkowy, przeł. M. Surma-Gawłowska, posł. G. Jankowicz, P. Mościcki, Kraków 2008, Linia Krytyczna, 2.

Arendt H., Korzenie totalitaryzmu, t. 1-2, przeł. D. Grinberg, M. Szawiel, Warszawa 2008.

Baumgold D., Hobbes's Political Theory, Cambridge 1988.

Brown S.M. Jr., Hobbes. The Taylor Thesis, „The Philosophical Review” 1959, Vol. 68, nr 3, s. 303-323, [online] http://dx.doi.org/10.2307/2182565.

Czernyszewski Z., Rortyego wizja nowej filozofii a relatywizm i imperializm kulturowy, [w:] Oblicza postmoderny. Teoria i praktyka uczestnictwa w kulturze wspótczesnej, red. A. Zeidler-Janiszewska, Warszawa 1992, Wokót Przedmiotu Postmodernistycznego.

Dudek A., Historia polityczna Polski 1989-2005, Kraków 2007, Arkana Historii.

Foucault M., Foucault Reader, ed. P. Rabinow, New York 1984.

Foucault M., Power/Knowledge. Selected Interviews and Other Writings 1971-1977, ed. C. Gordon, New York 1980.

Foucault M., Rzadomyślność, [w:] L. Rasiński, D. Leszczyński, Historia, wtadza, polityka, Warszawa-Wrocław 2002, s. 163-185.

Gauthier D., David Hume, Contractarian, „The Philosophical Review” 1979, Vol. 88, nr 1, s. 3-38, [online] http://dx.doi.org/10.2307/2184777.

Gauthier D., Morality and Advantage, „The Philosophical Rewiev” 1967, t. 76, nr 4, s. 460-475, [online] http://dx.doi.org/10.2307/2183283.

Gauthier D., Symposium Papers, Comments and an Abstract. Hobbes's Social Contract, „Noûs” 1988, Vol. 22, nr 1, s. 71-82, [online] http://dx.doi.org/10.2307/2215553.

Gauthier D., The Logic of Leviathan. The Moral and Political Thought of Thomas Hobbes, Oxford 1969.

Gauthier D., Thomas Hobbes. Moral Theorist, „The Journal of Philosophy” 1979, Vol. 76, nr 10, [online] http://dx.doi.org/10.2307/2025550. 
Goldsmith M.M., Hobbes's „Mortal God”. Is There Fallacy in Hobbes's Theory of Sovereignty?, [w:] The Social Contract Theorist. Critical Essays on Hobbes, Locke and Rousseau, ed. Ch.W. Morris, Maryland 1999, s. 24-40.

Hampton J., Hobbes and Ethical Naturalism, „Philosophical Perspectives” 1992, Vol. 6, s. 333 -353, [online] http://dx.doi.org/10.2307/2214251.

Hampton J., Hobbes and Social Contract Tradition, Cambridge 1986.

Hampton J., The Failure of Hobbes's Social Contract Argument [w:] The Social Contract Theorists. Critical Essays on Hobbes, Locke and Rousseau, ed. Ch.W. Morris, Maryland 1999, s. 41-59.

Hindess B., Filozofie wtadzy: od Hobbesa do Foucaulta, przeł. D. Leszczyński, L. Rasiński, Warszawa-Wrocław 1999.

Hobbes T., Elementy filozofii, t. 1-2, przeł. Cz. Znamierowski, Warszawa 1956, Biblioteka Klasyków Filozofii.

Hobbes T., Lewiatan, czyli Materia, forma i wtadza państwa kościelnego i świeckiego, przeł. Cz. Znamierowski, Warszawa 1954, Biblioteka Klasyki Filozofów.

Hoekstra K., Hobbes and the Foole, „Political Theory” 1997, Vol. 25, nr 5, s. 620-654, [online] http://dx.doi.org/10.1177/0090591797025005002.

Kavka G.S., Hobbsian Moral and Political Theory, Princeton 1986.

Kavka G.S., The Rationality of Rule-Following. Hobbes's Dispute with the Fool, „Law and Philosophy" 1995, Vol. 14, nr 1, s. 5-34, [online] http://dx.doi.org/10.2307/3504931.

Krasnodębski Z., Już nie przeszkadza. Szkice polityczne III, Kraków 2010, Biblioteka Myśli Politycznej, 73.

Nozick R., Anarchy, State, and Utopia, New York 1974.

Oakeshott M., Introduction to Leviathan, Oxford 1949.

Panichas G.E., Hobbes, Prudence and Basic Rights, „Noûs” 1988, Vol. 22, nr 4, s. 555-571, [online] http://dx.doi.org/10.2307/2215457.

Piotrowicz R., Od materii Świata do materii Państwa. Z filozofii Tomasza Hobbesa, Kraków 2000.

Podniesiński M., Dlaczego Anglosasi nie lubiq Foucaulta?, „Civitas. Studia z filozofii polityki” 2010, nr 13.

Podniesiński M., Symulacja spoteczeństwa europejskiego, [w:] Politikon III. Kto jest suwerenem?, red. M. Rysiewicz, M. Podniesiński, Kraków 2011.

Putnam H., Why Reason Can't Be Naturalized, [w:] tenże, Realism and Reason, Cambridge 1983.

Rawls J., Teoria sprawiedliwości, przeł. M. Panufnik, J. Pasek, A. Romaniuk, Warszawa 1994, Biblioteka Wspótczesnych Filozofów.

Rorty R., Filozofia a zwierciadto natury, przeł. M. Szczubiałka, Warszawa 1994, Biblioteka Aletheia.

Rorty R., Pierwszeństwo demokracji wobec filozofii, [w:] tegoż, Obiektywność, relatywizm, prawda, przeł. J. Margański, Warszawa 1999, Pisma filozoficzne, t. 1.

Skinner Q., Conquest and Consent. Thomas Hobbes and the Engagement Controversy, [w:] The Interregnum. The Quest for Settlement, 1646-1660, ed. G.E. Aylmer, London 1972.

Strauss L., O tyranii, red. V. Gourevitch, M.S. Roth, przeł. P. Armada, A. Górnisiewicz, Kraków 2009, Politika. 
Strauss L., The Philosophy of Hobbes, Chicago 1963.

Świat 2025. Scenariusze Narodowej Rady wywiadu USA, przeł. A. Krzynówek, M. Modrzejewska, wstęp J. Staniszkis, Kraków 2009.

Taylor A.E., Ethical Doctrine of Hobbes, „Philosophy” 1938, Vol. 13, nr 52, s. 406-424, [online] http://dx.doi.org/10.1017/S0031819100014194.

Warrender H., The Political Philosophy of Hobbes, Oxford 1959.

Wudel W., Filozofia strachu i nadziei. Teoria spoteczna Tomasza Hobbesa, Warszawa 1971.

Mgr Michał PODNIESIŃSKI - absolwent Politologii oraz Filozofii Uniwersytetu Jagiellońskiego, doktorant na Wydziale Studiów Międzynarodowych i Politycznych Uniwersytetu Jagiellońskiego. Koordynator i prowadzący Studia filozofia polityki ONLINE na Wyższej Szkole Europejskiej im. J. Tischnera. Autor książki Prawda i wtadza. Myśl Michela Foucaulta w latach 1956-1977 (Kraków, 2012). Publikował m.in. w „Kwartalniku Filozoficznym”, „Politei”, „Civitas”, „Dialogach politycznych”, „Eódzkich studiach teologicznych”. Redaktor serii Politikon. 